University of Nebraska - Lincoln

DigitalCommons@University of Nebraska - Lincoln

Nebraska Cooperative Fish \& Wildlife Research Nebraska Cooperative Fish \& Wildlife Research Unit -- Staff Publications

2003

\title{
Yellow Jackets May Be An Underestimated Component Of An Ant- Seed Mutualism
}

\author{
Megan T. Bale \\ University of Kentucky \\ Jennifer A. Zettler \\ Armstrong Atlantic State University, zettleje@mail.armstrong.edu \\ Bradford A. Robinson \\ Clemson University \\ Timothy P. Spira \\ Clemson University \\ Craig R. Allen \\ University of Nebraska-Lincoln, callen3@unl.edu
}

Follow this and additional works at: https://digitalcommons.unl.edu/ncfwrustaff

Part of the Other Environmental Sciences Commons

\footnotetext{
Bale, Megan T.; Zettler, Jennifer A.; Robinson, Bradford A.; Spira, Timothy P.; and Allen, Craig R., "Yellow Jackets May Be An Underestimated Component Of An Ant-Seed Mutualism" (2003). Nebraska Cooperative Fish \& Wildlife Research Unit -- Staff Publications. 92.

https://digitalcommons.unl.edu/ncfwrustaff/92
}

This Article is brought to you for free and open access by the Nebraska Cooperative Fish \& Wildlife Research Unit at DigitalCommons@University of Nebraska - Lincoln. It has been accepted for inclusion in Nebraska Cooperative Fish \& Wildlife Research Unit -- Staff Publications by an authorized administrator of DigitalCommons@University of Nebraska - Lincoln. 


\title{
YELLOW JACKETS MAY BE AN UNDERESTIMATED COMPONENT OF AN ANT-SEED MUTUALISM
}

\author{
Megan T. Bale', Jennifer A. Zettler ${ }^{2,}$, Bradford A. Robinson ${ }^{3}$, \\ Timothy P. Spira 4 , And Craig R. Allen 5
}

\begin{abstract}
Yellow jackets (Hymenoptera: Vespidae) are attracted to the typically ant-dispersed seeds of trilliums and will take seeds from ants in the genus Aphaenogaster. To determine if yellow jacket, Vespula maculifrons (Buysson), presence interferes with seed foraging by ants, we presented seeds of Trillium discolor Wray to three species (A. texana carolinensis Wheeler, Formica schaufussi Mayr, and Solenopsis invicta Buren) of seed-carrying ants in areas where vespids were present or excluded. We found that interspecific aggression between yellow jackets and ants is species specific. Vespid presence decreased average foraging time and increased foraging efficiency of two of the three ant species studied, a situation that might reflect competition for a limited food source. We also found that yellow jackets removed more seeds than ants, suggestive that vespids are important, albeit underestimated, components of ant-seed mutualisms.
\end{abstract}

\section{INTRODUCTION}

Myrmecochory is from the Greek words for "ant" (myrmeco) and "to spread abroad" (khorein). Myrmecochory is a specialized type of seed dispersal found on most continents, involving ants that are attracted to seeds with lipid-rich attachments called elaiosomes (Berg 1975, Beattie and Culver 1981, Bond and Slingsby 1983, Sernander 1906, Touyama et al. 1997). Because the relationship between ants and elaiosome-bearing plants is potentially beneficial to each, the interaction is considered to be a mutualism (Handel and Beattie 1990). Genera of native ants that are known seed dispersers in the eastern United States include Camponotus, Crematogaster, Formica, and Prenolepis (reviewed in Beattie 1983). The red imported fire ant, Solenopsis invicta Buren, is also attracted to elaiosome-bearing seeds, but this non-native ant is probably not a beneficial seed disperser (Zettler et al. 2001b).

\footnotetext{
${ }^{1}$ University of Kentucky College of Medicine, Box 5, Chandler Medical Center, Lexington, KY, 30536; ${ }^{2}$ Department of Biology, Armstrong Atlantic State University, Savannah, GA 31419; ${ }^{3}$ Department of Biology Instruction, Clemson University, Clemson, SC 29634; ${ }^{4}$ Department of Biological Sciences, Clemson University, Clemson, SC 29634; ${ }^{5}$ US Geological Survey, SC Cooperative Fish and Wildlife Research Unit, Clemson University, Clemson, SC 29634; "Corresponding author-zettleje@mail.armstrong.edu.
} 
Ant-seed interactions can be influenced by the presence of yellow jackets (Hymenoptera: Vespidae). For example, Zettler et al. (2001a) observed yellow jackets taking seeds from Aphaenogaster texana carolinensis Wheeler. It is unknown if yellow jackets take seeds from species in other seed-carrying ant genera, but we suspect that ant aggression towards vespids might limit seed-seizing behaviors. Ants are known to prey on polistine wasps and yellow jackets (Dejean 2001, Gambino 1990).

The objectives of this study were to quantify the response of vespids toward three species of seed-carrying ants, to determine the effects of yellow jackets on average foraging time and efficiency by ants, and to compare seed removal frequency by yellow jackets and ants.

\section{MATERIALS AND METHODS}

Experiments were conducted in the Clemson University Experimental Forest (Pickens Co., SC) at the edge of an oak-hickory forest adjacent to a 4-year-old clearcut. At this forest edge, the foraging ranges of the ants A. texana carolinensis, Formica schaufussi Mayr, and $S$. invicta and of the yellow jackets Vespula maculifrons (Buysson) overlapped. Data were collected during July 26 to August 9, 2001 between the hours of 900 and 1200 when ambient ground temperatures ranged from 23 to $28{ }^{\circ} \mathrm{C}$ and when ants and yellow jackets were actively foraging. All experiments were terminated after $1 \mathrm{~h}$ of observations.

Seeds of Trillium discolor Wray were collected in July 2001 from North Carolina (Jackson Co.) and refrigerated at $4{ }^{\circ} \mathrm{C}$ until used. This plant species occurs in the Experimental Forest; however, we used seeds collected in North Carolina due to an inadequate supply in the South Carolina site. Other myrmecochores in the Forest included Hexastylis arifolia (Michaux) Small, Sanguinaria canadensis L., and Viola spp.

Voucher specimens of $T$. discolor ( $\# 56524$ ) were deposited in the Clemson University Herbarium, and specimens of yellow jackets $(V$. maculifrons) and ants (A. texana carolinensis, $F$. schaufussi, and $S$. invicta) were deposited in the Clemson University Arthropod Collection.

Seed-seizing experiment. To determine if yellow jackets take more seeds from native seed-dispersing ants ( $F$, schaufussi and $A$, texana carolinensis) than from the red imported fire ant $(S$. invicta), we presented seeds of $T$. discolor to ant colonies in areas where yellow jackets were actively foraging. In addition, we simultaneously recorded the foraging time (time to take each seed into the nest) of ants in the presence of yellow jackets (treatment) and with vespids excluded (control). This experiment was replicated 4 times for Aphaenogaster and Solenopsis and 3 times for Formica. For all replicate experiments, ant species were randomized to eliminate day-to-day variability, and ant 
colonies were not reused. Five seeds were placed on an index card (positioned $30 \mathrm{~cm}$ from an ant nest opening. We also placed an empty $T$. discolor capsule adjacent to seeds because trillium seeds fall free in clusters during capsule abscission (Case and Case 1997), and it is possible that capsules provide additional attraction to seed dispersers. For example, Jules (1996) observed yellow jackets removing seeds from the dehisced capsule of Trillium ovatum. An inverted plexiglas petri dish $(100 \times 15 \mathrm{~mm})$ covered seeds to exclude yellow jackets while allowing access to ants. Once ants discovered the seeds, the petri dish was removed from the treatment to allow vespid foraging. As controls, the petri dish remained in place for the duration of the experiment to exclude yellow jackets from the seed cache. In each treatment, we recorded ant-vespid interactions and the total number of seeds removed by ants and yellow jackets.

Seed-removal experiment. To determine the seed-removal success (number of seeds carried from index cards) by ants and yellow jackets, we placed one seed each on 25 index cards in August 2001. Cards were evenly spaced $40 \mathrm{~cm}$ from each other in 5 vertical and 5 horizontal columns of index cards. This vertical and horizontal arrangement allowed two observers to record ant and vespid behaviors, interactions, and seed removal successes and failures (seeds abandoned after discovery) for up to $1 \mathrm{~h}$.

\section{RESULTS AND DISCUSSION}

In the seed-seizing experiment, we found that yellow jackets seized $25 \%(5 / 20)$ of the seeds carried by $A$. texana carolinensis, but not as many from $F$. schaufussi $(7 \%$ or $1 / 15)$ and fire ants $(5 \%$ or $1 / 20)$. We suggest that the success of yellow jackets in seizing seeds from ants is dependent on which ant species is carrying seeds.

Differences in ant aggression towards yellow jackets might explain differences in seed-seizing behaviors. On three occasions, $F$. schaufussi attacked vespids by lunging toward them, landing on their thorax or abdomen, and attempting to bite them. Following each of these aggressive interactions, vespids fled the area, and $F$. schaufussi retained the seeds. Solenopsis invicta also exhibited aggression towards yellow jackets. Fire ants gasterflagged at yellow jackets on 18 occasions, and $S$. invicta workers opened their mandibles ( 25 times observed) when vespids came near seeds $(<5 \mathrm{~cm})$. In contrast, yellow jackets assumed the role of aggressor when interacting with $A$. texana carolinensis. On 5 occasions, vespids flew in and touched these ants with their legs, whereas vespids never initiated contact with $F$. schaufussi or $S$. invicta. Moreover, A. texana carolinensis dropped and abandoned seeds on 18 occasions when disturbed by yellow jackets, whereas $F$. schaufussi and $S$. 
invicta never abandoned seeds in the presence of vespids. During preliminary experiments, we observed two yellow jackets approaching fire ants on tuna baits, and noted that each vespid was grounded when an ant seized a forewing with its mandibles. We observed these grounded yellow jackets trying unsuccessfully to remove the ants from their wings. After a two-hour struggle, the fire ants were missing their abdomens and had died, but still remained attached to the vespid wings.

Paradoxically, we found that yellow jackets indirectly might affect seed dispersal by ants by actually increasing ant foraging efficiency (number of seeds taken into nests). We found that when yellow jackets were excluded from seed caches, A. texana carolinensis failed to disperse 4 of 20 seeds. In contrast, all 20 seeds were taken from index cards when yellow jackets were present. Similarly, $F$, schaufussi failed to take 6 seeds $(40 \%)$ when yellow jackets were excluded and left only one $(7 \%)$ seed in the presence of vespids. We found the same to be true for seeds presented to $S$. invicta. In the presence of vespids, only $1(5 \%)$ seed remained on index cards, whereas $8(40 \%)$ seeds were not dispersed when vespids were excluded. Although our sample size was too small to perform statistical tests, the presence of yellow jackets seems to increase foraging efficiency of ants.

Yellow jackets might also indirectly affect seed dispersal by altering the amount of foraging time of ants. We observed that when yellow jackets were excluded, fire ants masticated elaiosomes and imbibed their fluids without removing the seeds from index cards. In the presence of yellow jackets, however, foraging times by $S$. invicta decreased by more than half (average $=36.3$ versus $15.8 \mathrm{~min}$ ). Likewise, the foraging times for $F$. schaufussi averaged $26.8 \mathrm{~min}$ when vespids were excluded and only $2.8 \mathrm{~min}$ in the presence of yellow jackets. We suggest that interspecific competition for food sources could initiate faster foraging or increased ant recruitment, which in turn would increase foraging efficiency. In addition, faster foraging by native seed dispersers could be beneficial to myrmecochores by reducing chance discovery of their seeds by seed predators (e.g., rodents).

Table I. Percent of seeds ( 25 total) removed from index cards, average time (min) from the start of the experiment to when seeds were removed from the index cards, and percent of discovered seeds abandoned by ants (Aphaenogaster texana carolinensis, Formica schaufussi, Solenopsis invicta) and yellow jackets (Vespula maculifrons) in Clemson, SC, in August 2001.

\begin{tabular}{|c|c|c|c|c|c|}
\hline & $\begin{array}{l}\text { A. texana } \\
\text { carolinensis }\end{array}$ & F. schaufussi & S. invicta & V. maculifrons & Other $^{*}$ \\
\hline Tof seeds removed & 8 & 28 & 8 & 40 & 16 \\
\hline Average seed removal time & 20.0 & 24.6 & 32.0 & 29.2 & 20.0 \\
\hline \% of seeds abandoned & 0 & 12.5 & 0 & 0 & 0 \\
\hline
\end{tabular}


We suggest that yellow jackets are important transporters of Trillium seeds, a genus typically considered to be ant dispersed. Not only did yellow jackets seize seeds from seed-carrying ants, but they also removed more $(40 \%)$ seeds from index cards than did each of the three ant species (Table 1). We saw up to 5 yellow jackets foraging on index cards at any one time. Ants in the genus Aphaenogaster are considered to be efficient and common seed dispersers in eastern forests (Beattie 1985). However, we found that A. texana carolinensis removed only $8 \%$ of seeds from index cards. We found that $16 \%$ of seeds were taken by two species of carpenter ants (Camponotus pennsylvanicus and $C$. americanus). This genus is also considered to be a seed-disperser (reviewed in Beattie 1983), but we did not observe any Camponotus-vespid interactions during our experiments.

Dispersal by yellow jackets might be especially important for myrmecochorous plants with summer seed production because ants tend to switch to insect prey as the season progresses (Culver and Beattie 1978). In some areas, yellow jackets might be primary seed dispersers for elaiosome-bearing species. For example, Jules (1996) observed yellow jackets dispersing seeds of $T$. ovatum in southwestern Oregon; however, he never witnessed ants carrying seeds. Yellow jackets can potentially disperse seeds further than ants (Jules 1996, Zettler et al. 2001a), which might benefit plants by increasing their habitat ranges. The fate of seeds taken by yellow jackets has not been investigated. However, because fire ants are attracted to and damage elaiosome-bearing seeds (Zettler et al. $2001 \mathrm{~b}$ ), seed dispersal by vespids might especially benefit myrmecochores in habitats where fire ants and yellow jackets overlap.

\section{ACKNOWLEDGMENTS}

We thank S.T. Brock and S. Perry for technical support and P.H. Adler and F.W. Zettler for helpful comments on the manuscript. The South Carolina Cooperative Fish and Wildlife Research Unit is jointly supported by a cooperative agreement among the USGS/BRD, the South Carolina Department of Natural Resources. Clemson University, and the Wildlife Management Institute. This research was partially supported by a grant from the Clemson University Enhancement of Research and Extension Programs in Imported Fire Ant Biology.

\section{LITERATURE CITED}

Beattie. A.J. 1983. Distribution of ant-dispersed plants. Sonderbande des Naturwissenschaftlichen Vereins in Hamburg 7:249-270.

Beattie, A.J. 1985. The Evolutionary Ecology of Ant-Plant Mutualisms. Cambridge University Press, New York, NY. 182 pp.

Beattie. A.J.. and D.C. Culver. 1981. The guild of myrmecochores in the herbaceous flora of West Virginia forests. Ecology 62:107-115.

Berg, R.Y. 1975. Myrmecochorous plants in Australia and their dispersal by ants. Australian Journal of Botany 23:475-508. 
Bond, W.J., and P. Slingsby. 1984. Collapse of an ant-plant mutualism: The Argentine ant (Iridomyrmex humilis) and myrmecochorous Proteaceae. Ecology 65:1031-1037.

Case, F.W., and R.B. Case. 1997. Trilliums. Timber Press, Portland, OR . 285 $\mathrm{pp}$.

Culver, D.C., and A.J. Beattie. 1978. Myrmecochory in Viola: Dynamics of seed-ant interactions in some West Virginia species. Journal of Ecology $66: 53-72$

Dejean, A.. J. Orivel, B. Corbara, I. Olmsted, and J.P. Lachaud. 2001. Nest site selection by two Polistine wasps: The influence of Acacia-Pseudomyrmex associations against predation by army ants (Hymenoptera). Sociobiology $37: 135-146$.

Gambino, P. 1990. Argentine ant Iridomyrmex humilis (Hymenoptera: Formicidae) predation on yellow jackets (Hymenoptera: Vespidae) in California. Sociobiology 17:287-198.

Handel, S.N., and A.J. Beattie, 1990. Seed dispersal by ants. Scientific American 263:76-83.

Jules. E.S. 1996. Yellow jackets (Vespula vulgaris) as a second seed disperser for the myrmecochorous plant. Trillium ovatum. American Midland Naturalist 135:367-369.

Sernander. R. 1906. Entwurf einer Monographie der Europäischen Myrmekochoren. Kungl. Svenska Veternskapsaka demiens Handlingar $41: 1-409$.

Touyama, Y., N. Nakagoshi, and T. Yamamoto. 1997, Myrmecofauna of lucidophyllous forests in different developmental stages in South-Western Japan. Ecological Research 12: 131-138.

Zettler, J.A., T.P. Spira, and C.R. Allen. 200la, Yellow jackets (Vespula spp.) disperse Trillium (spp.) seeds in Eastern North America. American Midland Naturalist 146:444-446.

Zettler, J.A.. T.P. Spira, and C.R. Allen. 2001b. Ant-seed mutualisms: Can red imported fire ants sour the relationship? Biological Conservation 101:249 253. 